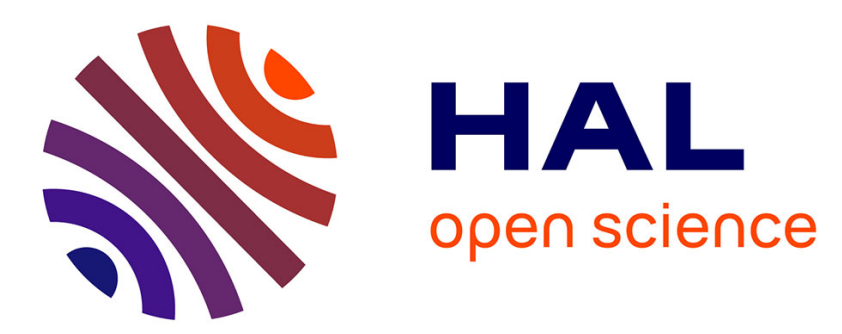

\title{
The effect of etching on bacterial microleakage of an adhesive composite restoration
}

\author{
Peter E Murray, Thomas W Smyth, Imad About, Remeille Remusat, \\ Jean-Claude Franquin, Anthony J Smith
}

\section{To cite this version:}

Peter E Murray, Thomas W Smyth, Imad About, Remeille Remusat, Jean-Claude Franquin, et al.. The effect of etching on bacterial microleakage of an adhesive composite restoration. Journal of Dentistry, 2002, 30 (1), pp.29-36. 10.1016/s0300-5712(01)00055-0 . hal-03552501

\section{HAL Id: hal-03552501 \\ https://hal.science/hal-03552501}

Submitted on 2 Feb 2022

HAL is a multi-disciplinary open access archive for the deposit and dissemination of scientific research documents, whether they are published or not. The documents may come from teaching and research institutions in France or abroad, or from public or private research centers.
L'archive ouverte pluridisciplinaire HAL, est destinée au dépôt et à la diffusion de documents scientifiques de niveau recherche, publiés ou non, émanant des établissements d'enseignement et de recherche français ou étrangers, des laboratoires publics ou privés.

\section{(ㅇ)(1) $\$$}

Distributed under a Creative Commons Attribution - NonCommercial - NoDerivatives| 4.0 


\title{
The effect of etching on bacterial microleakage of an adhesive composite restoration
}

\author{
Peter E. Murray ${ }^{\mathrm{a}, \mathrm{b}, *}$, Thomas W. Smyth ${ }^{\mathrm{c}}, \operatorname{Imad}_{\text {About }}{ }^{\mathrm{d}}$, Remeille Remusat $^{\mathrm{d}}$, \\ Jean-Claude Franquin ${ }^{\mathrm{d}}$, Anthony J. Smith ${ }^{\mathrm{b}}$ \\ ${ }^{a}$ Oral Biology, Indiana University School of Dentistry, 1121 West Michigan Street, Indianapolis, IN 46202, USA \\ ${ }^{\mathrm{b}}$ Oral Biology, 7th Floor, School of Dentistry, The University of Birmingham, St Chad's Queensway, Birmingham B4 6NN, UK \\ ${ }^{\mathrm{c}}$ St Anthonys Hospital, Oklahoma City, OK, USA \\ ${ }^{\mathrm{d}}$ Laboratoire Interface Matrice Extracellulaire Biomateriaux, Faculté d'Odontologie, Université del la Méditerranée, \\ 27 Boulevard Jean Moulin, 13385 Marseille cedex 5, France
}

\begin{abstract}
Objectives: The incidence of bacterial microleakage, pulp inflammation and necrosis associated with dentine etching treatments prior to restoration are not known. Consequently, to resolve some of the controversy surrounding the effects and importance of vital dentine etching, the authors investigated these factors.

Methods: 110 standardised class V cavities were cut into buccal dentine, without exposing the pulp of teeth scheduled for extraction for orthodontic reasons. Cavities were either left unetched, or etched with the non-equivalent treatments of phosphoric acid gel for $60 \mathrm{~s}$ or Ethylenediaminetetraacetic acid (EDTA) for $30 \mathrm{~s}$, prior to placement of composite resin. Teeth were collected and pulp responses were evaluated according to ISO guidelines, using pathohistomorphometric analysis and ANOVA statistics.

Results: Etching was found to be correlated to bacterial microleakage $(p=0.0001)$ and tertiary dentine formation $(p=0.0023)$. Bacterial microleakage was correlated to inflammatory activity $(p=0.0001)$. The frequency of bacterial microleakage was: no etching $(65 \%)$, EDTA $(51 \%)$ and phosphoric acid (PA) $(20 \%)$.

Significance: Vital dentine etching treatment is of extreme importance for the placement of RC to minimise bacterial microleakage. PA etching proved to be more effective at preventing bacterial microleakage than non-etching, and etching with EDTA.
\end{abstract}

Keywords: Pulp; Microleakage; Inflammation; Adhesives; Phosphoric acid

\section{Introduction}

The use of acid etching to condition instrumented cavity surfaces by removing the smear layer has become a standard procedure in restorative dentistry. The smear layer is a 1$5 \mu \mathrm{m}$ thick layer [1] of denatured cutting debris produced on instrumented cavity surfaces, and is composed of dentine, odontoblastic processes, non-specific inorganic contaminants and microorganisms [2,3]. The smear layer is also forced variable distances into the dentinal tubules beneath the instrumented cavity surfaces [4]. The advantages and disadvantages of the presence of smear layer, and whether it should be removed or not from the instrumented dentine surfaces, are still controversial [5]. Cavity conditioning requires little time but provides the benefit of better adaption of the restorative or intermediate base to dentine [6]. Hence attention has generally focused on the removal of smear layer to condition cavity preparations for the dentine bonding of restorative materials $[7,8]$. In the past, there was an initial resistance to the use of acid etching and adhesive systems to place composite restorations following reports of necrosis and inflammation [6]. However, over the past 10 years, the consensus over acid etching of vital dentine has changed, following reports dispelling fears over inflammation [9]. Nevertheless, because of these conflicting data, some questions still remain over the relationships between acid etching, bacterial microleakage, pulp inflammation, and the incidence of necrosis and degree of pulp injuries underlying etched vital dentine. 
Table 1

Number of teeth according to etching treatments and postoperative extraction time intervals

\begin{tabular}{|c|c|c|c|c|c|c|}
\hline \multirow[t]{2}{*}{ Group number } & \multirow[t]{2}{*}{ Etching } & \multicolumn{5}{|c|}{ Postoperative extraction time (days) } \\
\hline & & $20-40$ & $41-60$ & $61-100$ & $101-381$ & Total \\
\hline 1 & Phosphoric acid & 10 & 10 & 6 & 9 & 35 \\
\hline 2 & Ethylenediaminetetraacetic acid & 10 & 13 & 9 & 3 & 35 \\
\hline 3 & No treatment & 11 & 21 & 4 & 4 & 40 \\
\hline
\end{tabular}

Caries has been identified as the most frequent cause for the failure of restorations [10,11]. Microleakage complications involve inflammation, necrosis, recurrent caries, postoperative sensitivity, periodontal disease, and the eventual need for endodontic therapy $[12,13]$. Although the relationship between pulp infection, inflammation, and pulp necrosis, has already been established, controversy remains as to the possible differences between etching treatments, and their ability to prevent bacterial microleakage and pulpal necrosis in patients.

Conventionally, the smear layer has been removed with phosphoric acid (PA) or maleic acid, with the objective of enhancing the adhesion of resin composite, or resin modified glass ionomers to enamel and vital dentine surfaces. However, there are other types of etchants in use. Citric acid is the most commonly used etchant in periodontal therapy, and ethylenediaminetetraacetic acid (EDTA) has been used to remove the smear layer in cavity and root canal preparations. Smear layer removal with each of these etchants has been associated with various observations of tissue injury and repair activity [14]. In recent years, the use of a $\mathrm{pH}$ neutral etching solution of EDTA, has been found to be as effective as low $\mathrm{pH}$ etchants for smear layer removal [15]. Although the bond strength of restorative materials after EDTA application has been examined [16], comparatively little attention has been paid to the pulpal responses following vital dentine etching with EDTA. Of the etchants in clinical use, EDTA is the only one chelating agent at neutral $\mathrm{pH}$, while the low $\mathrm{pH}$ of $\mathrm{PA}$ acts by dissolving or eroding a mineralised surface [17]. Consequently, there is a need to evaluate the pulp response to vital dentine etching with EDTA, to determine if smear layer removal with EDTA can confer some advantages to restorations, in comparison with PA. Furthermore, the smear layer has come under extensive scrutiny in recent years, and many benefits and liabilities of it's retention beneath restorations have been observed. These include, acting as a cavity liner to reduce dentine permeability to the possible cytotoxicity of restorative materials [18], as well as being a liability to restoration longevity, due to the bacteria it can harbour beneath restorations [18]. Characterisation of the effects of etching treatments on vital dentine should help the practitioner to choose to retain the smear layer or remove it with PA or EDTA. Consequently the purpose of this study was to evaluate the incidence of bacterial microleakage, severity of pulp inflammation and injury and repair responses, following the placement of resin composite in unexposed cavities, following smear layer removal with EDTA and PA, as well as with not etched smear layer.

\section{Materials and methods}

One hundred and ten teeth, scheduled for extraction for orthodontic reasons from healthy patients ( $63.4 \%$ female) aged between 9 and 25 years of age, had class V cavities prepared in non-carious intact first or second maxillary or mandibular premolars. Teeth were extracted between 20 and 381 days following cavity preparation, etching and extraction, using a local anaesthetic with patient and parental informed consent in Marseille Hospital dental care centres. Our standardised methods and procedures used in this study have been described elsewhere [19-22]. Briefly, class V cavity preparations were placed in the buccal surface of teeth, $1 \mathrm{~mm}$ above the level of the cementoenamel junction.

Preparation forms were cut into the tooth dentine using the least possible pressure at a drill speed of 400,000 revolutions per minute with water spray coolant. Cavity dimensions were estimated during cutting, however a histometric analysis of the histological sections found the cavities were cut into dentine to a range of cavity remaining dentine thicknesses (RDT) between 0.008 and $1.610 \mathrm{~mm}$, and axial floor widths between 1.01 and $3.39 \mathrm{~mm}$.

Teeth were assigned to three experimental groups (1-3) for restoration (Table 1). All the products were used strictly according to their manufacturers instructions. Group 1: Enamel and dentine cavity walls were etched with $37 \%$ PA gel. The gel was left in place for $60 \mathrm{~s}$ and then rinsed for $30 \mathrm{~s}$ with water. This was followed by air-drying for $20 \mathrm{~s}$. Adhesive (Scotchbond duel cure, 3M Dental, St. Paul, MN, USA) was applied to the cavity walls using the brush supplied for the purpose. The cavity was then dried for $30 \mathrm{~s}$ to remove alcohol from the resin. This procedure was repeated for a second coating of adhesive. The RC system (Silux, 3M Dental, St. Paul, MN, USA) was then used to fill the cavity and was polymerised with a curing light for 40 s. Group 2: Following cavity preparation, 17\% EDTA (dentine conditioner, 3M Dental Products, St. Paul, MN, USA) was applied to cavity calls for $30 \mathrm{~s}$ to remove smear layer, and then rinsed for $30 \mathrm{~s}$ with water. This was followed by air-drying for $20 \mathrm{~s}$. These teeth were restored 
Table 2

Frequency bacterial microleakage, inflammation and necrosis following cavity etching $(n=$ number of teeth)

\begin{tabular}{|c|c|c|c|c|c|c|c|c|}
\hline \multirow[t]{3}{*}{ Etching Treatment } & \multicolumn{2}{|l|}{ Total } & \multicolumn{6}{|c|}{ Inflammation category } \\
\hline & \multirow[b]{2}{*}{+ Bact } & \multirow[b]{2}{*}{ - Bact } & \multicolumn{2}{|c|}{ Absent/slight } & \multicolumn{2}{|l|}{ Moderate } & \multicolumn{2}{|l|}{ Necrosis } \\
\hline & & & + Bact & - Bact & + Bact & - Bact & + Bact & - Bact \\
\hline No etching & $65 \% \%(n 26)$ & $35 \%(n 14)$ & $50 \%(n 8)$ & $50 \%(n 8)$ & $75 \%(n 18)$ & $25 \%(n 6)$ & $0 \%(n 0)$ & $0 \%(n 0)$ \\
\hline EDTA & $51 \%(n 18)$ & $49 \%(n 17)$ & $38 \%(n)$ & $62 \%(n 5)$ & $57 \%(n 13)$ & $43 \%(n 10)$ & $50 \%\left(\begin{array}{ll}n & 2\end{array}\right)$ & $50 \%(n 2)$ \\
\hline Phosphoric acid & $20 \%(n 7)$ & $80 \%(n$ 28) & $0 \%(n 0)$ & $100 \%(n 14)$ & $19 \%(n 3)$ & $81 \%(n 13)$ & $80 \%(n 4)$ & $20 \%(n 1)$ \\
\hline
\end{tabular}

with Scotchbond/Silux as described above. Group 3: The cavities in this category were left unetched and were restored with Scotchbond/Silux as described above. Extracted teeth were prepared for light microscopy and a histomorphometric analysis was conducted, as described previously [19-22]. Briefly, $5 \mu \mathrm{m}$ tooth sections were stained with haematoxylin and eosin, the area of tertiary dentine was estimated histomorphometrically at $10 \times$ magnification using a grid eyepiece graticule, and the RDT was also measured. Odontoblasts with a distinct nuclei and intact cytoplasm were counted beneath the cavity preparations per $\mathrm{mm}^{2}$ unit of pulp area, as well as odontoblast numbers per $\mathrm{mm}^{2}$ opposite and independent of the cavity preparation.

Pulpal inflammatory responses were categorised as either absent/slight, moderate or severe, on the basis of standards set by the Federation Dentaire Internationale and International Organisation for Standardisation, and previously published criteria $[23,24]$. Essentially, in addition to other distinguishable pathological features, 'necrosis' was observed as disintegration of pulp tissue, particularly a complete disintegration of odontoblasts beneath the cavity floor. A moderate response indicated a reduction of the odontoblasts, localised inflammatory lesions, as well as tissue infiltration of polynuclear lymphocytes or polynuclear leukocytes. An absence or slight inflammatory response indicated that the odontoblast layer appeared normal, and few inflammatory cells were observed. Bacterial contamination of the restorations, or the underlying dentinal tubules, was assessed using the Brown-Brenn procedure [25] for the presence of gram positive and negative bacteria. The raw numerical data was examined using multivariate Analysis of Variance (ANOVA) (StatView software, SAS). These procedures are reportedly among the most versatile and most conservative of the multiple comparison tests [26].

\section{Results}

\subsection{Bacterial microleakage}

The Brown-Brenn procedure identified bacteria in $43.6 \%$ of all the restored cavities. The ability of cavity etching to prevent the microleakage of bacteria varied, the rank order of materials was; PA (80\%), EDTA (49\%) non-etched $(35 \%)$ (Table 2). Overall, the use of cavity etching was found to be very important to prevent bacterial microleakage of the cavity preparations (ANOVA $p=0.0001$.) Furthermore, the quantity of bacteria in non-etched cavities, was found to be much greater than following EDTA or PA etching (Fig. 1).

\subsection{Pulp inflammatory activity}

Pulpal inflammatory activity was not found to be increased by etching treatments (ANOVA $p=0.0936$ ) rather inflammatory activity was found to be correlated with bacterial microleakage (ANOVA $p=0.0001$.) Necrosis was observed primarily in the presence of bacterial microleakage with PA etching, and also following EDTA etching (Table 2). Higher grades of inflammation were observed following bacterial microleakage into cavities, which were etched with PA (Fig. 2). The lowest levels of inflammatory activity were observed in cavities, which were non-etched (Fig. 2). Moreover, no pulp necrosis was observed in any cavities, which were non-etched, although these cavities appeared to contain the highest levels of bacterial contamination (Table 2). This is presumably because the bacteria in non-etched cavities did not invade tubules and migrate closer to the pulp than in etched cavities.

\subsection{Odontoblast density}

Odontoblast density was reduced beneath cavities, in comparison with odontoblast density independent of the cavity preparation (ANOVA $p=0.0001$ ). However, these reductions in odontoblast numbers may be attributed to cavity preparation trauma, rather than an effect of etching, as odontoblast density was not reduced significantly beneath cavities with a RDT below $0.5 \mathrm{~mm}$, in comparison with those with a RDT above $0.5 \mathrm{~mm}(p=0.8238)$ (Fig. 3).

\subsection{Tertiary dentine area}

A histomorphological evaluation of the extracted premolar specimens revealed the presence of a tertiary dentine matrix beneath $66 \%$ of the restorations. In all cases, a tubular continuity was maintained between the secondary dentine matrix and the preexisting odontoblasts. These 


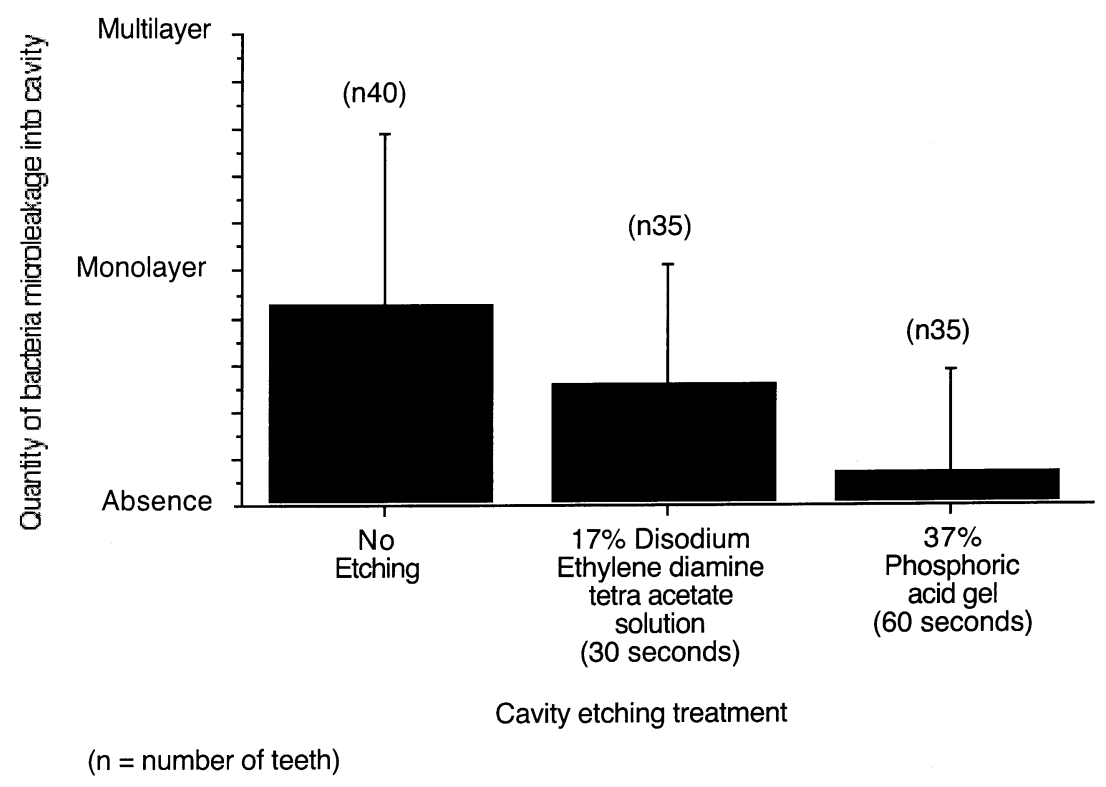

Fig. 1. Quantity of bacterial microleakage into cavities.

observations classify the secreted tertiary dentine matrix as reactionary in origin [27,28], and consequently our observations of tertiary dentine activity should not be confused with dentine bridge formation, which is an entirely different form of dentine repair activity.

Etching treatments of vital dentine appeared to be correlated with increases in tertiary dentine activity (ANOVA $p=0.0023$ ). EDTA etching of vital dentine, appeared to increase the area of tertiary dentine beneath cavities with a RDT less than $0.5 \mathrm{~mm}$, while PA etching did not appear to appreciably influence the tertiary dentine activity (Fig. 4).

\subsection{Analysis of the postoperative extraction time within} groups to ensure the test comparisons were valid

Bacterial microleakage, pulpal response to bacterial leakage and the area of tertiary dentine might be expected to be dependent on the postoperative extraction time. However in this study, conducted between 20 and 381 days, no

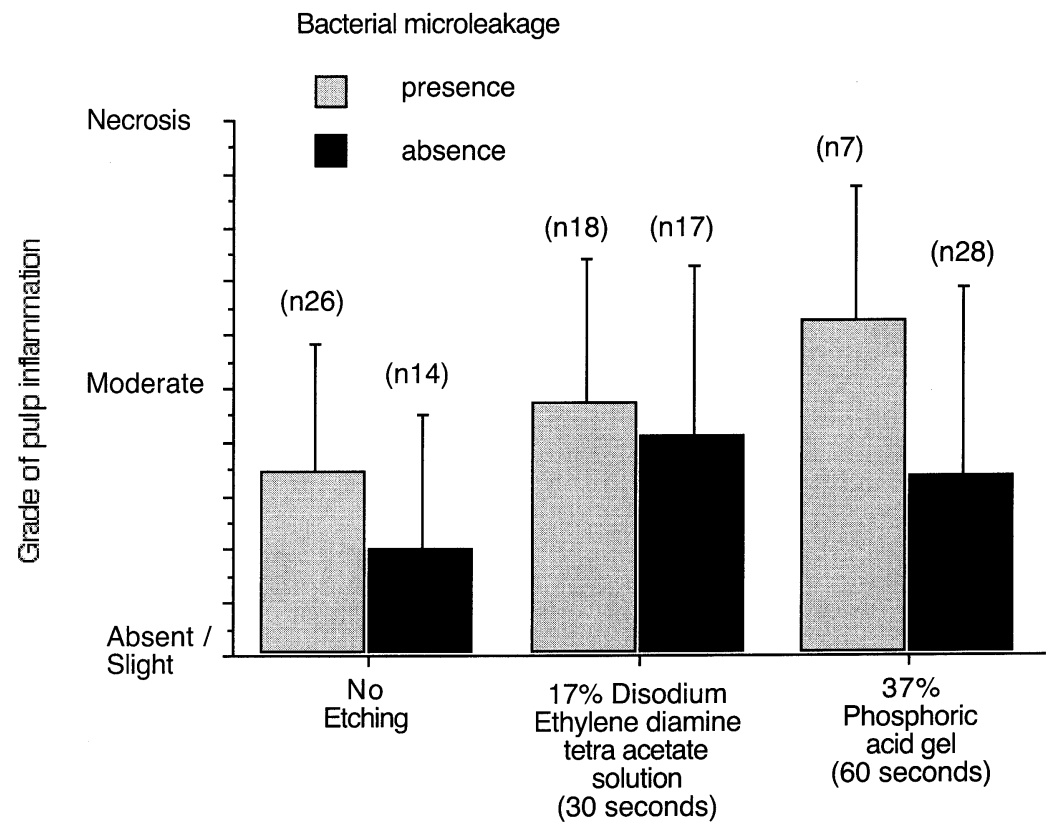

Cavity etching treatment

$(\mathrm{n}=$ number of teeth)

Fig. 2. Pulp inflammatory activity following vital dentine etching. 
Beneath cavities with a remaining dentine thickness below $0.5 \mathrm{~mm}$

Beneath cavities with a remaining dentine thickness above $0.5 \mathrm{~mm}$

Independent of cavity

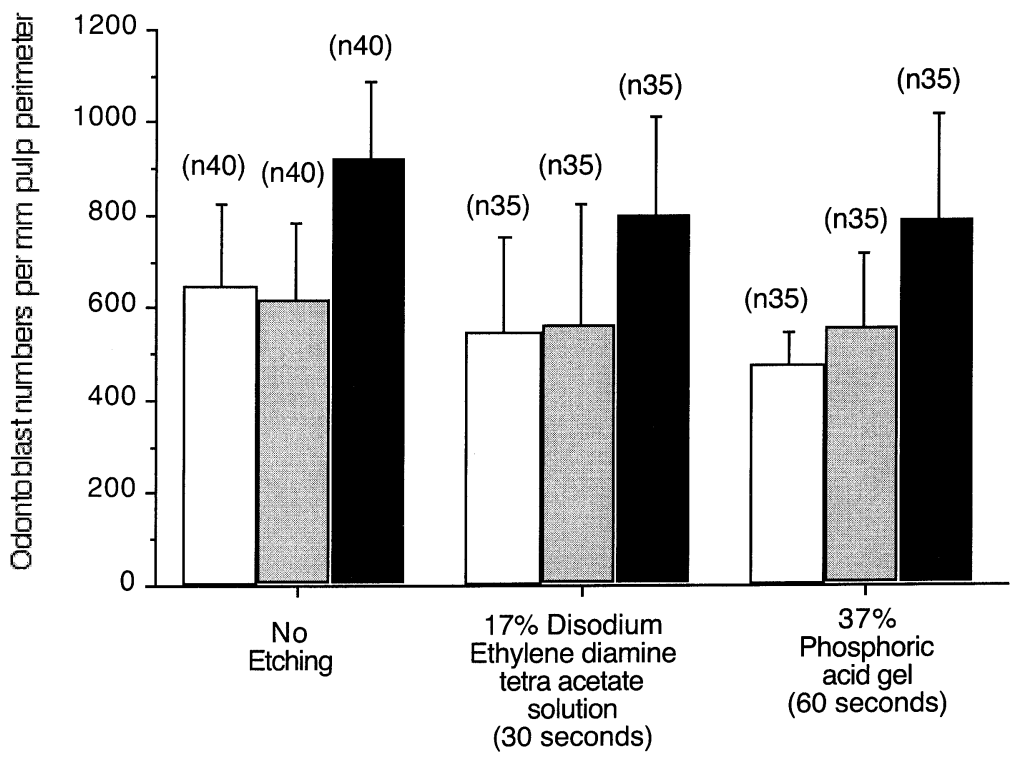

Cavity etching treatment

( $\mathrm{n}=$ number of teeth)

Fig. 3. Odontoblast density following vital dentine etching.

Cavity remaining dentine thickness

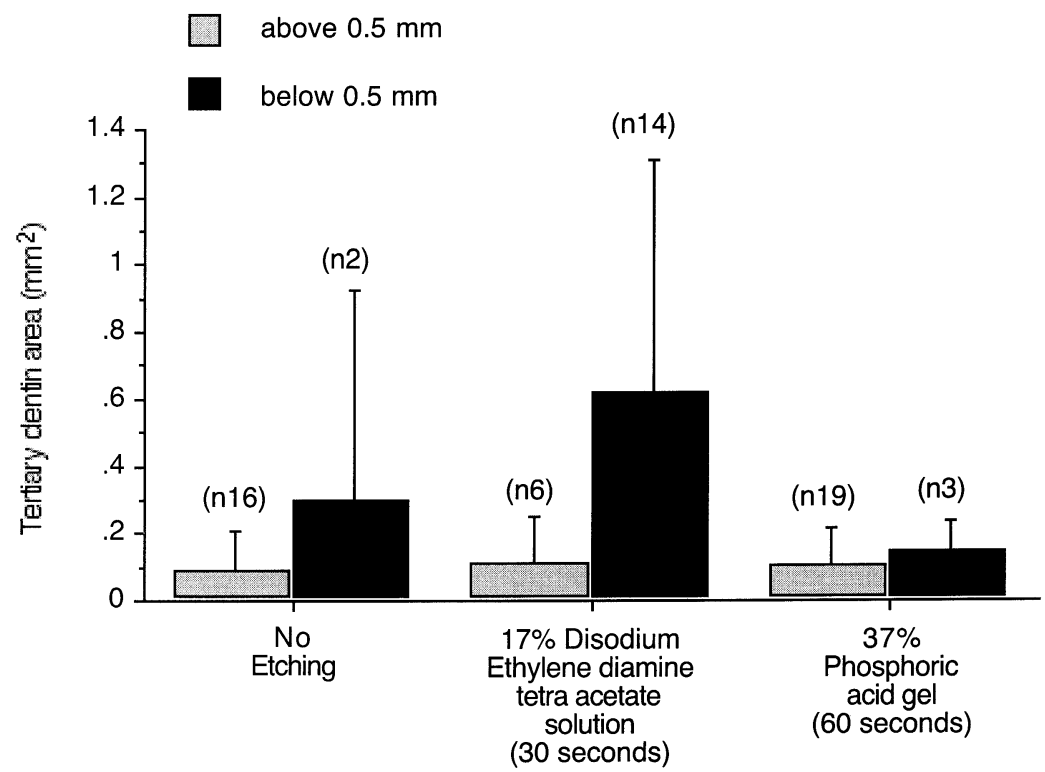

Cavity etching treatment

( $n=$ number of teeth)

Fig. 4. Tertiary dentine area following vital dentine etching. 
significant differences were observed at the $p=0.05$ level using multivariate ANOVA statistics.

\subsection{Analysis of the cavity remaining dentine thickness within groups to ensure that the test comparisons were valid}

To remove the possibility of a mismatch of RDT's between each of the restoration variables, the RDTs were measured and compared with each other using multivariate ANOVA statistics. No differences were observed at the $p=0.05$ significance level.

\section{Discussion}

According to many longitudinal investigations, there remains a high number of primarily vital teeth which exhibit symptoms requiring endodontal treatment, following restorative treatments [29]. Consequently, there is a need to examine all aspects of cavity preparation and restoration, to identify possible sources of pulp injury, which may mediate these post-operative complications. This information may prove useful to guide clinicians as to where to concentrate their efforts in order to reduce the frequency of postoperative complications in patients. Often pulp responses have been ascribed to the activity of particular restorative materials, with seemingly little regard given to the possible effects of vital dentine etching treatments, and other factors such as the dimensions of the cavity preparation forms. Recent studies have indicated that pulp responses are the summation of all the cavity preparation and restoration events, in addition to patient factors such as age and history [19-22]. However, evidence is lacking to explain the relationships between vital dentine etching, bacterial microleakage and pulp inflammation, which cause pulp pathology. This justified our attempt to evaluate the variables of vital dentine etching with PA and EDTA, as well as to evaluate the effects of non-etching of vital dentine prior to the placement of resin composite, using morphometric and analytical evaluation. Preparation of cavities in caries-free teeth, avoided the possibility of including residual caries effects within the data, and pulp responses were examined according to ISO guidelines.

Vital dentine etching and smear layer removal appears to have been best studied at the electron microscopical level to evaluate the hybridisation interface between adhesive bonded materials and tooth structure. Nevertheless, little previous efforts has been made to examine the effects of vital dentine etching treatments, or the presence of smear layer on underlying pulp tissue in patients. However, this study has highlighted the importance of vital dentine etching in terms of underlying pulpal responses. Vital dentine etching can affect the incidence of bacterial microleakage, increase the severity of pulp inflammatory activity, increase tertiary dentine secretion, and decrease odontoblast cell density beneath restorations.

In the clinical situation, the adequate removal of smear layer is difficult to achieve. This explains attempts to develop adhesive products which did not require smear layer removal prior to filling [30]. However, these early products proved unsuccessful and low restoration bond strengths were reported [31,32]. In accord with these findings, our observations show that a failure to etch the smear layer permitted bacterial microleakage into $65 \%$ of cavity restorations (Table 2), and that relatively high quantities of bacteria were present in these cavities (Fig. 1). Moreover, in accord with previous observations [17,18], our findings indicate that the presence of smear layer also appeared to prevent the further microleakage of bacteria through cut dentinal tubules in a pulpward direction as no necrotic pulps were observed (Table 2), and this explains why the level of inflammatory activity was generally less than that observed with PA or EDTA etching (Fig. 2). Furthermore, it has been suggested that the presence of smear layer, containing trapped bacteria $[17,18]$ and denatured smear layer debris [33] could diffuse through the dentine floor of the cavity preparations, and increase the level of pulp injury in comparison with etched dentine cavity restorations. Our observations show that the density of odontoblasts beneath unetched vital dentine was maintained at higher levels than following EDTA or PA etching (Fig. 3). These observations suggest that non-etching of vital dentine can be beneficial for pulp responses in some respects. However, the length of this study was limited to 380 days, and our observations of high-levels of bacterial colonisation of these non-etched cavity restorations, would almost certainly result in a high frequency of pulp complications with time. The onset of recurrent caries beneath posterior composites can take place within 6 months of a cavosurface margin defect [34]. In the clinical situation, the presence of a smear layer has been observed to prevent the formation of an adequate seal between the cavity surface and the restoration, resulting in microleakage and eventual pulpal inflammation $[35,36]$. The effect of this, is that the cavity restoration will fail more quickly, than it would if the smear layer was removed [6]. On the basis of this evidence and the results presented in this study, non-removal of smear layer prior to filling with resin composite cannot be recommended for work on patients.

On the other hand, the application of etchants to remove smear layer has long been an issue of concern for pulp viability $[36,37]$. Despite reports that EDTA can be less harmful to oral tissues when removing smear layer [15], EDTA has also been reported to be cytotoxic to tissues [38] and EDTA treatment of a pulp exposure or a very deep cavity preparation is not recommended [6]. These observations highlight the difficulty in assessing the possible effects of vital dentine etching. Although lower quantities of bacteria were detected in cavities following EDTA dentine etching, in comparison with cavities which were non-etched (Fig. 1), more than $50 \%$ of EDTA etched cavity restorations were found to be infected with bacteria (Table 2). This would suggest that EDTA etching marginally improves 
the bacteriometic sealing of adhesive bonded composite to teeth, but is not as effective as PA (Table 2). Odontoblast density beneath EDTA etched vital dentine was found to decrease to similar levels as unetched and PA treated cavities (Fig. 3) suggesting that reductions in odontoblast cell survival beneath vital dentine, was more the result of cavity preparation trauma, than the primary effects of vital dentine etching treatments.

One effect of vital dentine etching with EDTA, which as not observed with PA etching or non-etching treatments, was a large increase in tertiary dentine deposition beneath cavities, with a RDT below $0.5 \mathrm{~mm}$ (Fig. 4). The stimulatory effect of EDTA on tertiary dentine area may be a result of solubilisation of endogeneous growth factors from the dentine matrix $[39,40]$. Growth factors such as Transforming Growth Factor Beta (TGF $\beta$ ) and bone morphogenic proteins, may play a critical role in dentinogenic events $[41,42]$. EDTA can solubilise a number of dentine matrix components [40] including growth factors, and it's chelating action at neutral $\mathrm{pH}$ [15] may contribute to this action. Thus smear layer removal with EDTA in accordance with the manufacturers recommended treatment, may be beneficial to the patient in terms of pulpal repair response, and contribute to greater bond strength of restorations [32]. However, it is unlikely to be effective if the RDT is above $0.5 \mathrm{~mm}$.

In terms of bond strengths, the presence of smear layer in non-etched cavities (Group 3) probably produced low adhesive bond strengths. Although evidence is generally lacking to explain the relationship between bond strength and bacteriometic sealing, the observations of a high level of microleakage in these restorations (Table 2), suggest that low bond strengths may be related to a reduction in the quality of bacteriometic sealing. The etching treatments evaluated in this present study are not equivalent. The $30 \mathrm{~s}$ of etching with $17 \%$ EDTA is a less active etching treatment than $60 \mathrm{~s}$ of etching with $37 \%$ PA. To acheive the same degree of etching with PA, the EDTA would probably have to be applied for 5-10 min. The EDTA etching (Group 2) of cavity walls probably increased the bond strength of adhesive to enamel, in comparison with nonetched cavities. However EDTA etching has been observed to reduce the already low bond strength of the original duelcure Scotchbond to dentine [43]. Thus, the EDTA etched cavities were probably only adequately bonded at the acidetched enamel interface. This relatively small area of bonding could reduce the quality of bateriometic sealing, culminating in over $50 \%$ of restorations becoming contaminated with bacteria (Table 2). In Group 1, the PA etching removed the enamel and dentine smear layers, thereby increasing the resin-enamel bonds to $20 \mathrm{MPa}$, but lowering the resin-dentine bonds [43]. Presumably, the same result occurred with EDTA etching, but the enamel bonds were not as high, because EDTA probably did not remove the entire enamel smear layer. The greater enamel bond strength associated with PA etching [43] may be related to superior bacteriometic sealing, explaining the low numbers of restorations contaminated with bacteria (Table 2). These observations, together with continual improvements in the enamel and dentine bonding performance of adhesive systems [44], explain the need to periodically examine these adhesive systems clinically.

There has been a noticeable lack of consensus about the effects of smear layer and etching treatments to remove smear layer [4,18]. After considering all the effects of EDTA and PA etching, as well as the effects of non-etching vital dentine, seemingly the most important factor to prevent pulp complications, and maintain restoration longevity $[13,38,45]$ is postulated to be the ability of the restoration to prevent bacterial microleakage. Consequently as more than $50 \%$ of non-etched and EDTA etched cavity restorations became infected, compared with only $20 \%$ of PA etched cavity restorations (Table 2), smear layer removal with PA must be recommended in preference to EDTA etching and non-etching of vital dentine. However, this does represent a compromise since there will be minimal tertiary dentine deposited beneath PA etched restorations. Furthermore, our quantitation of bacteria represents only total cell numbers and does not consider their relative metabolic activity.

We have shown that the incidence, and quantity of bacterial contamination, is correlated to the presence of smear layer and vital dentine etching treatments. The presence of bacteria increases the severity of pulp inflammation. Etching treatments can also influence underlying odontoblast density and tertiary dentine repair activity. It is now clear that the use of the most appropriate vital dentine etching treatment, can provide clinicians with the ability to minimise the incidence of bacterial microleakage, inflammation and pulp necrosis, although this does require a compromise in terms of tertiary dentine repair activity.

\section{References}

[1] Brännström M, Nordenvall K-J, Glanz P-O. The effect of EDTAcontaining surface-active solutions on the morphology of prepared dentin: an in vivo study. J Dent Res 1980;59:1127-31.

[2] Czonstkowsy M, Wilson EG, Holstein FA. The smear layer in endodontics. Dent Clin N Am 1990;34:13-25.

[3] Takeda FH, Harashima T, Kimura Y, et al. A comparative study of the removal of smear layer by three endodontic irrigants and two types of laser. Int Endodont J 1999;32:32-9.

[4] Pashley DH. Smear layer: an overview of structure and function. Proc Finnish Dent Soc 1992;88(Suppl 1):S215-24.

[5] Sen BH, Wesselink PR, Turkun M. The smear layer: a phenomenon in root canal therapy. Int Endodont J 1995;28:141-8.

[6] Llindemann RA, Hume WR, Wolcott RB. Dentin permeability and pulpal response to EDTA. J Prosthetic Dent 1985;53:341-3.

[7] White GJ, Beech DR, Tyas MJ. Dentin smear layer: an asset or a liability for bonding? Dent Mater 1989;5:379-83.

[8] Santinin A, Mitchell S. A scanning electron microscopic study of the effect of Gluma CPS bonding system on dentinal smear layers produced by different bur types and rotational speeds and on the reson-dentin interface. Quintess Int 1998;29:737-47.

[9] Akimotot N, Momoi Y, Kohno A, et al. Biocompatibility of Clearfil 
liner bond 2 and Clearfil AP-X system on nonexposed and exposed primate teeth. Dent Mater 1998;29:177-88.

[10] Maupome G, Sheiham A. Criteria for restoration replacement and restoration life-span estimates in an educational environment. J Oral Rehab 1998;25:896-901.

[11] Burke FJ, Cheung SW, Mjör IA, et al. Reasons for the placement and replacement of restorations in vocational training practices. Primary Dent Care 1999;6:17-20.

[12] Bergenholtz G, Cox CF, Loesche WJ, et al. Bacterial leakage around dental restorations; its effect on the dental pulp. J Oral Pathol 1982; 11:439-50.

[13] Cox CF. Microleakage related to restorative procedures. Proc Finnish Dent Soc 1992;88(Suppl 1):83-93.

[14] Poldon AM, Federick GT, Ladenheim S, et al. The production of a root surface smear layer by instrumentation and its removal by citric acid. J Periodontol 1994;55:443-6.

[15] Blomof J, Lindskog S. Root surface texture and early cell and tissue colonisation after different etching modalities. Eur J Oral Sci 1995; 103:17-24.

[16] Vougioklakis G, Smith DC, Lipton S. Evaluation of the bonding of cervical restorative materials. J Oral Rehab 1982;9:231-5.

[17] Pashley DH. Smear layer: physiological considerations. Operative Dent 1984;3(Suppl):13-29.

[18] Gwinnett AJ. Smear layer: morphological considerations. Operative Dent 1984;3(Suppl):S3-S12.

[19] Murray PE, About I, Lumley PJ, et al. Postoperative pulpal and repair responses. J Am Dent Ass 2000;131:321-9.

[20] Murray PE, About I, Lumley PJ, et al. Human odontoblast cell numbers after dental injury. J Dent 2000;28:277-85.

[21] Murray PE, Lumley PJ, Ross HF, et al. Tooth slice organ culture for cytotoxicity assessment of dental materials. Biomaterials 2000;21: 1711-21.

[22] Murray PE, About I, Franquin J-C, et al. Restorative pulpal and repair responses. J Am Dent Ass 2001;132:482-91.

[23] Mjör IA. Biological and clinical properties. In: Mjor IA, editor. Dental materials, biological properties and clinical evaluation, Boca Raton: CRC Press, 1985. p. 91-121.

[24] Mjör IA. Current views on biological testing of restorative materials. J Oral Rehab 1990;17:503-7.

[25] Lille RD, Fulmer HM. Histopathologic technique and practical histochemistry. 4th ed. New York, USA: McGraw-Hill, 1976.

[26] Dawson-Saunders B, Trapp RG. Basic and clinical biostatistics. 2nd ed. Norwalk, CN, USA: Appleton and Lange, 1994.

[27] Mjör IA. Dentin and pulp. Reaction patterns in human teeth. Florida: CRC Press, 1983. p. 63-156.
[28] Smith AJ, Cassidy N, Perry H, et al. Reactionary dentinogenesis. Int J Dev Biol 1995;39:273-80.

[29] Zöllner A, Gaengler P. Pulp reactions to different preparation techniques on teeth exhibiting periodontal disease. J Oral Rehab 2000;27:93-102.

[30] Eick JD, Gwinnett JD, Pashley DH, et al. Current concepts on adhesion to dentin. Crit Rev Oral Biol Med 1997;8:306-35.

[31] Tao L, Pashley DH, Boyd L. Effect of different types of smear layers on dentin and enamel shear bond strengths. Dent Mater 1988;4: 208-16.

[32] Tao L, Tagami J, Pashley DH. Effects of pulpal pressure on bond strengths of superbond and gluma. Am J Dent 1991;4:73-6.

[33] Eick JD. Smear layer-materials surface. Proc Finnish Dent Soc 1992;88:225-42.

[34] Leinfelder KF. Criteria for clinical evaluation of composite resin restorations. In: Anusavice K, editor. Quantity evaluation of dental restorations, Chicago: Quintess Publishing Co, 1989. p. 95-110.

[35] Pashley DH. Clinical considerations of microleakage. J Endodont 1990;16:70-7.

[36] Cox CF. Evaluation and treatment of bacterial microleakage. Am J Dent 1994;7:293-5.

[37] Pameijer CH, Stanley HR. Pulp reaction to a dentin bonding agent. Am J Dent 1995;8:140-4.

[38] Torneck CD. Reaction of hamster tissue to drugs used in sterilization of the root canal. Oral Surg Oral Med Oral Pathol 1961;14:730-47.

[39] Finkelman RD, Mohan RD, Jennings JC, et al. Quantitation of growth factors IGF-I, SG/IGF-II and TGF- $\beta$ in human dentine. J Bone Miner Res 1990;5:717-23

[40] Cassidy N, Fahey M, Prime SS, et al. Comparative analysis of transforming growth factor-beta isoforms $1-3$ in human and rabbit dentine matrices. Archs Oral Biol 1997;42:219-23.

[41] Sloan AJ, Smith AJ. Stimulation of the dentine-pulp complex of rat incisor teeth by transforming growth factor $-\beta$ isoforms $1-3$ in vitro. Archs Oral Biol 1999;44:149-56.

[42] Takata T, D'Errico JA, Atkins KB, et al. Protein extracts of dentin affect proliferation and differentiation of osteoprogenitor cells in vitro. J Periodontol 1998;69:1247-55.

[43] Pashley EL, Tao L, Derkson G, et al. Dentin permeability and bond strength after various surface treatments. Dent Mater 1989;5:375-8.

[44] Kugel G, Ferrari M. The science of bonding: from first to sixth generation. J Am Dent Assoc 2000;13:139-47.

[45] Camps J, Dejou J, Remusat M, et al. Factors influencing pulpal response to cavity restorations. Dent Mater 2000;16:432-40. 